\title{
The New Institutional Economics and Development Theory: A Brief Critical Assessment
}

\author{
PRANAB BARDHAN \\ University of California, Berkeley
}

\begin{abstract}
Summary. - In this paper we discuss strengths and weaknesses of transaction-cost and imperfect-information approaches to the economic theory of institutions, particularly with reference to problems relevant to economic development.
\end{abstract}

\section{ALTERNATIVE THEORIES}

In recent years two strands of non-Walrasian economic literature have developed wellarticulated endogenous theories of institutions, and they are both getting to be prominent in the new microeconomics of development. One is the transaction cost school, flowing out of the famous paper by Coase (1960), followed by the writings of Alchian, Demsetz, Williamson, North and others; the other school is associated with the theory of imperfect information as in the work of Akerlof, Stiglitz, Spence and others. Although there is some family resemblance between the two strands, there are important differences in their points of emphasis. But they both deny the validity of some of the principal results of mainstream economics. For example, one of the main pillars of Walrasian neoclassical economics - the separability of equity and efficiency breaks down when transaction costs and imperfect information are important; the terms and conditions of contracts in various transactions, which directly affect the efficiency of resource allocation, now crucially depend on ownership structures and property relations. Development economics, which deals with cases where market failure and incomplete markets (often the result of the substantive presence of transaction costs and information problems) are predominant, clearly provides hospitable territory for such institutional analysis.

According to the transaction costs school, institutions that evolve to lower these costs are the key to the performance of economies. These costs include those of information, negotiation, monitoring, coordination and enforcement of contracts. When transaction costs are absent, the initial assignment of property rights does not matter from the point of view of efficiency, because rights can be voluntarily adjusted and exchanged to promote increased production. But when transaction costs are substantial, as is usually the case, the allocation of property rights is critical. In the historical growth process there is a tradeoff between economies of scale and specialization on the one hand and transaction costs on the other. In a small, closed, face-to-face peasant community, for example, transaction costs are low, but the production costs are high, because specialization and division of labor are severely limited by the extent of market defined by the personalized exchange process of the small community. In a large-scale complex economy, as the network of interdependence widens the impersonal exchange process gives considerable scope for all kinds of opportunistic behavior (cheating, shirking, moral hazard) and the costs of transacting can be high. In Western societies over time, complex institutional structures have been devised (elaborately defined and effectively enforced property rights, formal contracts and guarantees, corporate hierarchy, vertical integration, limited liability, bankruptcy laws and so on) to constrain the participants, to reduce the uncertainty of social interaction, in general to prevent the transactions from being too costly and thus to allow the productivity gains of larger scale and improved technology to be realized. North and Thomas (1973) have explained economic growth of Western Europe between the 10th and the 18th centuries primarily in terms of 
innovations in the institutional rules that governed property rights. In this view, as in Marxist history, property relations which were socially useful at one time become "fetters" on the further development of the forces of production, and an appropriate redefinition of property rights becomes necessary. New property rights emerge that allow an increase in gains from trade by economizing on transaction costs (including gains from new production or exchange which were unprofitable under earlier high transaction costs and the consequent "market failure"). North and many other neoclassical institutional economists believe that the basic source of institutional change is fundamental and persistent changes in relative prices, which lead one or both parties in a transaction to perceive that they could be better off under alternative contractual and institutional arrangements. Historically, population change is judged to have been the single most important source of relative price changes, though technological change (including that in military technology) and changes in the costs of information are also deemed as major sources.

The imperfect-information theory of institutions is closely related to that of transaction costs, since information costs constitute an important part of transaction costs. But the former theory is usually cast in a more rigorous framework clearly spelling out assumptions and equilibrium solution concepts, drawing out more fully the implications of strategic behavior under asymmetric information and sharply differentiating the impact of different types of information problems. Imperfect-information theory yields somewhat more concrete and specific predictions about the design of contracts, with more attention to the details of terms and conditions of varying contractual arrangements under varying circumstances, than the usual presentations of transaction cost theory. Exceptions in the latter are provided by Williamson's theory of transactionspecific assets and his theory of incomplete contracts as further developed by Hart and Holmstrom (1987). The latter focus on adaptive sequential decision making rather than the comprehensive contingent claims contracts of the imperfect-information literature. The imperfectinformation theorists give more emphasis to $e x$ ante mechanism design in contracts and less to maladaptation costs incurred when transactions drift out of alignment ex post in a world of bounded rationality where contracts are necessarily incomplete (i.e., cannot possibly take into account all contingencies). In particular, once relation-specific investments (i.e., where the investments the parties make have a much greater use inside the relationship than outside) are made, there is scope for post-contractual opportunistic behavior. Institutional devices to reduce this consist usually of long-term contractual relations or integration of firms (converting an arms-length transaction into an internal one and defining property rights as the default option in incomplete contracts). Long-term implicit contracts and personalized, less-than-armslength transactions are, of course, quite common in developing countries, although Williamson's immediate concern is with the corporate structure and practices in industrially advanced countries.

The imperfect-information theory has been fruitfully used in modeling many key agrarian institutions which are seen to emerge as substitutes for missing credit, insurance and futures markets in an environment of pervasive risks, information asymmetry and moral hazard. ${ }^{1}$ It started with the literature on sharecropping, then on interlocking of transactions in labor, credit and land lease, on labor tying, on credit rationing and so on. Radical economists have often cited some of these production relations as institutional obstacles to development in a poor agrarian economy, overlooking the microeconomic rationale of the formation of these institutions. Under a set of informational constraints and missing markets, a given agrarian institution (say, sharecropping or interlocking of contracts) may be serving a real economic function. Its simple abolition, as is often demanded on a radical platform, without taking care of the factors that gave rise to the institution in the first place, may not necessarily improve the conditions of the intended beneficiaries of the abolition program. There may be some important political lessons here from what can be called the economics of second-best reformism.

\section{FUNCTIONALISM AND OTHER LIMITATIONS}

The transaction-cost and imperfect-information theories are equally murky on the mechanism through which new institutions and property rights emerge. One gets the impression that more efficient institutions and governance structures evolve as the parties involved come to appreciate the new benefit-cost possibilities. The literature is marked ${ }^{2}$ by a certain ahistorical functionalism and even vulgar Darwinism on this point. An institution's mere function of serving the interests of potential beneficiaries is clearly inadequate in explaining it, just as it is an incompetent detective who tries to explain a murder mystery only by looking for the benefici- 
ary and, on that basis alone, proceeds to arrest the heir of the murdered rich man. One cannot get away from the enormity of the collective action problem that limits the ability of potential gainers to get their act together in bringing about institutional changes. There are two kinds of collective action problems involved here: one is the well known free-rider problem about sharing the costs of bringing about change, the other is a bargaining problem where disputes about sharing the potential benefits from the change may lead to a breakdown of the necessary coordination.

We have noted before the neoclassical institutional economists' strong belief that relative price changes fuel the main motive force for institutional changes in history (primarily by inducing the development of property rights to the benefit of the owners of the more expensive factor of production). In particular, demographic changes altering the relative price of labor to land lead to the incentive for redefinition of property rights on land and a rearrangement of labor relations: North (1981) and Hayami and Ruttan (1985) give several examples from European and recent Asian history respectively. But from Brenner's analysis (1976) of the contrasting experiences of different parts of Europe on the transition from feudalism (those between Western and Eastern Europe and those between the English and the French cases even within Western Europe) we know that changes in demography, market conditions and relative prices are not sufficient to explain the contrasts. Changes in relative prices may at most change the costs and benefits of collective action for different classes (creating new opportunities for political entrepreneurs) but cannot predetermine the balance of class forces or the outcome of social conflicts. Hayami and Ruttan (1985) refer to the case of mid-19th century Thailand, where the expansion of international trade triggered a rise in rice prices which led to a major transformation of property rights: traditional rights in human property (corvée and slavery) were replaced by more precise private property rights in land. But one should not forget that the expansion of grain trade in 16th and 17th century Poland had helped the relapse into serfdom. There are other examples of institutional stagnation or retrogression following upon expansion of trade in more recent colonial history.

A related question is that of the presumed optimality of persistent institutions. The transaction-cost (as well as the imperfect-information) school often unthinkingly implies the application of the market analogy of competitive equilibrium to the social choice of institutions or the biological analogy of natural selection in the survival of the fittest institution. In fact transaction costs themselves, by raising barriers to entry and exit, reduce pressures from any social selection process; sunk costs and asset-specificity insulate internal governance structures from market forces. As Greenwald and Stiglitz (1986) have shown, the market equilibrium under imperfect information and incomplete markets is, in general, constrained Pareto inefficient; and, as Farrell (1987) has shown, with imperfect information even bilateral relationships may not be efficient on account of complexity of private bargaining.

In the recent development literature the institution of interlocking of transactions (in labor, credit and land relations) has been rationalized as a device to save transaction costs and to substitute for incomplete or nonexistent credit and insurance markets. But one should not overlook that such interlocking itself may act as a barrier to entry for third parties and be a source of additional monopoly power for the dominant partner (usually the employer-creditor-landlord) in such transactions. Personalized interlocking of labor commitments and credit transactions (involving selective exclusion of others) also divide the workers and emasculate their collective bargaining strength vis-à-vis employers, who use this as an instrument of control over the labor process.

As we all know from experience, dysfunctional institutions often persist for a very long period. Akerlof (1984) has built models to show how economically unprofitable or socially unpleasant customs may persist as a result of a mutually sustaining network of social sanctions when each individual conforms out of fear of loss of reputation from disobedience. In such a system, potential members of a breakaway coalition fear that it is doomed to failure and thus failure to challenge the system becomes a self-fulfilling prophecy. Kuran (1987) has a related model of collective conservatism which is reinforced by the influence on an individual's private preference formation of the justifications others give for their public preferences for the status quo. A similar selfreinforcing mechanism for the persistence of socially suboptimal institutions may be in operation when path-dependent processes are important, as is now recognized in the literature of the history of technological innovations. (The QWERTY typewriter keyboard, the narrow gauge of British railroads, US color television system, etc. have been given as examples of the persistence of technologies that were ex ante inferior.) As Arthur (1985, 1988) has emphasized, when there are increasing returns to adoption of a particular (technological or institu- 
tional) innovation - i.e., the more it is adopted the more it is attractive or convenient for the others to join the bandwagon on account of infrastructural and network externalities, learning and coordination effects and adaptive expectations - a path chosen be some initial adopters to suit their interests may "lock-in" the whole system for a long time to come, denying later, more appropriate, technologies or institutions a footing. This lock-in happens dynamically as sequential decisions "groove" out an advantage from which the system finds it hard to escape. The process is non-ergodic; there are multiple outcomes and historical "small events" early on may well decide the larger course of structural change. ${ }^{3}$

The biological analogy of survival of the fittest is particularly inappropriate as path dependence is assigned an important role in biological processes. To quote Gould (1980, p. 16): "Organisms are not billiard balls propelled by simple and measurable external forces to predictable new positions on life's pool table ..... Organisms have a history that constrains their future in myriad, subtle ways . . .. Their complexity of form entails a host of functions incidental to whatever pressures of natural selection superintended the initial construction." The arguments against the operation of natural selection in social institutions are obviously much stronger.

The recognition of path dependence does not necessarily lead to a completely chaotic or "Cleopatra's-nose" view of institutional history. There are certain regularities in the evolution of social institutions as social agents repeatedly face the same types of social problems and adapt their behavior. Schotter (1981) and Sugden (1986) have given game-theoretical accounts of the spontaneous evolution of institutions as selfenforcing stable solutions to iterated games of strategy. Sugden analyzes the evolution of three kinds of institutional rules or what he calls conventions: (1) conventions of coordination which evolve out of repeated play of games of pure coordination (examples from social life are: road rules, use of money, weights and measures, marketplaces and market days, languages) where the degree of conflict of interests is minor; (2) conventions of property which evolve out of repeated play of games where the players are in dispute over something that they all want but all cannot have (examples from social life: "finders keepers" rule, queues, occupancy rights on land); and (3) conventions of reciprocity which evolve out of repeated plays of prisoner'sdilemma games (examples: practices of mutual restraint and mutual aid, and the highly suggestive success of tit-for-tat in Axelrod's (1984) well- known computer tournament). Schotter, similarly, has a model that depicts the process of institution creation as a Markovian diffusion process whose absorbing points correspond to a stable social institution; the institutional problem is phrased as a supergame. There is, of course, a certain amount of indeterminacy in such an analysis: we do not expect to isolate a unique institutional form as stable, rather we must content ourselves with a set of forms that, when taken together, are stable. Nor do these evolutionary processes necessarily maximize social welfare. Sugden's evolutionarily stable strategy, for example, is a Nash equilibrium, rather than some sort of cooperative equilibrium like the core or the Shapley value.

At this point it is also important to note, as many evolutionary economists remind us, the distinction that Carl Menger (1883) made between "organic" and "pragmatic" institutions. The contractarian approach of the transactioncost and imperfect-information schools emphasizes the latter, those which are the direct outcome of conscious contractual design, as in the case of some corporate structure and practices. Organic institutions like the conventions of Sugden and Schotter are, on the other hand, comparatively undesigned, and they evolve gradually as the unintended and unforeseeable result of the pursuit of individual interests. ${ }^{4}$ (As Francois Furet (1978), an historian of the French Revolution, observed, "men make history but they do not know which one.") Menger's theory of the origin of money, in which the selfinterested actions of traders led to the evolution from a barter economy to one in which a single commodity became the universal medium of exchange, is a prime example of the evolution of an organic institution. But unlike the case of Menger's theory of money, it is possible to have cases where an institution is created organically but preserved pragmatically. This is a case of what Elster (1983) calls "filter explanation," as opposed to functional explanation, where the actors eventually become aware of the function an institution serves for them and then consciously maintain it, even though it originally came into being unintended. Langlois (1986) gives an interesting (and ironical) example from Edelman's (1964) theory of government regulatory commissions: "Voters are plagued with vague fears about and a sense of powerlessness over certain phenomena they cannot control. The fear of monopoly is one of these. In order to gain votes, politicians make symbolic gestures to placate these fears - in this case, the formation of regulatory commissions. But, once in place, the commissions ... are quickly captured in the 
familiar way by those they were supposed to regulate. Thus a quite different mechanism maintains them once created; they serve the function of cartelizing the industry and are kept in business by the political action of that industry" (p. 251).

\section{POWER AND REDISTRIBUTTVE INSTITUTIONAL CHANGE}

The neoclassical institutional economists focus their attention on allocative efficiency-improving institutions, whereas Marxists often emphasize how institutions change or do not change depending on considerations of surplus appropriation by a dominant class. In particular, progress toward a more productive institution may be blocked if it reduces the control of surplus by this class. (Even when historically valid, such a statement, of course, needs better microfoundations, showing how individuals within the class that could gain from the new institution are frustrated in their efforts by the aggregative necessity of retaining control for the whole class.) The emphasis on the effect of an institutional change on control of surplus by a particular class also suggests that the question of efficiencyimproving institutional change cannot really be separated from that of redistributive institutional change. This is particularly true when issues of collective action, bargaining power, class capacity, mobilization and struggle in the historical process are important. This means that the distinction Hayami and Ruttan (1985) make between the "demand" for institutional innovations (on the basis of changes in technological or demographic factors) and their "supply" (depending on political entrepreneurs undertaking the necessary collective action) may be somewhat artificial. In empirical analysis of actual institutional changes this may lead to a kind of "identification problem." For example, in English agricultural history did the (second) enclosure movement in the 18th century come about because enclosed farming was more efficient than open-field farming, or because the (prospective) redistributive effect of enclosures in favor of landowners made collective action on their part easier? In the example of Hayami and Kikuchi (1982) from agriculture in the Philippines in the mid-1970s, where the increase in population pressure on land brought about a new employer-employee relationship (the gamma system replacing the traditional hunusan system) lowering the wage rate, did it come about because the disequilibrium between labor productivity and wage "demanded" such a change, or because population pressure on land made collective action on the part of employers easier (or that on the part of laborers weaker), thus facilitating the "supply" side? Taking another example from Hayami and Kikuchi (1982), the rapid expansion of labor-tying arrangements like kedokan in many parts of Java in the late 1960s, which are attributed to population growth by Hayami and Kikuchi are explained from the supply side by Hart (1986) with reference to the drastic changes in the collective strength of the poor peasantry brought about by the bloody political changes of the mid-1960s in Java.

A shift in the focus of attention from the efficiency aspects of an institution to the distributive aspects inevitably confronts us with the question of somehow grappling with the elusive concept of power and with political processes which much of neoclassical institutional economics would abhor. Marxists, of course, directly deal with these issues, but are often methodologically careless. The concept of power is often used in a question-begging way: differences in institutional arrangements are supposed to be explained by blanket references to differences in the power of the dominant class without an independent quantification of the latter. The literature - Marxist or non-Marxist - on a rigorous analysis of power is rather scanty in economics, ${ }^{5}$ compared to that in sociological and political theory. Game theorists have used the idea of bargaining power in dividing up the surplus in bargaining games, or the idea of power exercised as the Stackelberg leader taking the weaker party's reaction function as given, or as the ability to credibly precommit in noncooperative games - these are indirectly reflected in some of the models of the imperfect-information theory of institutions. In recent Marxist theoretical models in economics, two distinct forms of power relations have emerged: Roemer (1982) finds the primary locus of capitalist power in unequal distribution of property, whereas Bowles $(1985,1987)$ traces it to the political structures of control and surveillance at the point of production, both referring to a competitive economy. Roemer reiterates the well-known Samuelsonian proposition that in a competitive model it does not matter whether capital hires labor or labor hires capital, with the important modification that in either case the wealthy "exploit" (take advantage of) the poor. To Bowles, on the other hand, the locus of command in the production process is central to the functioning of the system. I find this distinction between domination in production and assetbased power somewhat overdrawn: who hires whom essentially depends on the capacity to be 
the residual claimant in production, and that in turn depends on the capacity to bear risks, the wealthy having obviously a larger riskbearing capacity. But both these strands of Marxist theory serve as a reminder that in the transaction-cost and imperfect-information theories demonstrating the economic rationale of some existing institutions in terms of transaction costs and moral hazard, it is underemphasized that a more democratic organization of the work process (following Bowles) or a more egalitarian distribution of assets (following Roemer) might have significantly reduced (not eliminated) the informational constraints and Hobbesian malfeasance problems which form the staple of much of the principal-agent games in the literature.

Marglin (1984) has argued that the large-scale factory organization did not evolve as a means of harnessing new technologies but, on the contrary, technologies were devised to ensure the factory system's success as a mode of control over workers. In general, capitalist authority relations in the internal organization of the firm and the labor process are usually described by radical economists as organizational devices to exercise power. Transaction-cost theorists like Williamson vigorously contest this. They point to functions of authority as a useful governance structure in restraining "worker opportunism" and in facilitating adaptability to changing circumstances (particularly in cases of assets that are not easily redeployable) by vesting in the asset owners the residual rights of discretionary control. But at the same time we should not ignore, as Dow (1987) points out, that such discretionary control, along with hierarchy and the division of labor, generates the structural preconditions for "employer opportunism." Employers are given strategic advantages of information over their employees, the ability to use fiat to resolve conflicts in self-serving ways, the opportunity for unilateral introduction of technical innovations which undercut the bargaining position of workers, and so on. In any case, since transaction costs can be as difficult to define and quantify as power, in actual empirical or historical analysis one may sometimes find it hard to unscramble the effects of one from the other.

\section{NOTES}

1. For an overview of the relevant literature, see Bardhan (1984), Stiglitz (1986) and Bardhan (1989).

2. There are, however, exceptions to this, like the more recent writings of North in the transaction cost school and of Stiglitz among imperfect information theorists.

3. One remembers Leontief's (1963) plea for "writing history backwards" when the dynamic system confronting the historian is unstable.
4. Buchanan (1975) in his explanation of the rise of property and law and Nozick (1974) in his discussion of the hypothetical emergence of a minimal state from a Lockean state of nature have used the idea of unintended outcomes of voluntary negotiations. On the other side of the political spectrum, Elster (1985) has given an insightful interpretation of Marxian dialectics in terms of unintended consequences in history.

5. For a discussion of the use of the concept of power in economics, see Bardhan (1988).

\section{REFERENCES}

Akerlof, G., An Economic Theorist's Book of Tales (Cambridge: Cambridge University Press, 1984).

Alchian, A., and H. Demsetz, "The property rights paradigm," Journal of Economic History, Vol. 33 (March 1973), pp. 16-27.

Arthur. B., "Self-reinforcing mechanisms in economics," in P. W. Anderson, and K. J. Arrow (Eds.), The Economy as an Evolving Complex System (Reading, MA: Addison Wesley, 1988).

Arthur, B., "Competing technologies and lock-in by historical small events," CEPR Publications No. 43 (Stanford, CA: Stanford University, December 1985).

Axelrod, R., The Evolution of Cooperation (New York: Basic Books, 1984).

Bardhan, P. (Ed.), The Economic Theory of Agrarian Institutions (Oxford: Oxford University Press, 1989).
Bardhan, P., "Some reflections on the use of the concept of power in economics," Working Paper (Berkeley, CA: University of California at Berkeley, 1988).

Bardhan, P., Land, Labor and Rural Poverty (New York: Columbia University Press, 1984).

Bell, C. J., "Credit markets, contracts and interlinked transactions," in H. B. Chenery, and T. N. Srinivasan (Eds.), Handbook of Development Economics (Amsterdam: North-Holland, 1988).

Bowles, S., "Contested exchange: A microeconomic analysis of the political structure of the capitalist economy," unpublished (1987).

Bowles, S., "The production process in a competitive economy: Walrasian, neo-Hobbesian and Marxian models," American Economic Review, Vol. 75 (March 1985), pp. 16-36. 
Brenner, R., "Agrarian class structure and economic development in preindustrial Europe," Past and Present, Vol. 70 (February 1976), pp. 30-70.

Buchanan, J., The Limits of Liberty (Chicago: University of Chicago Press, 1975).

Coase, R., "The problem of social cost," Journal of Law and Economics, Vol. 3 (October 1960), pp. $1-44$.

Dow, G., "The function of authority in transaction cost economics," Journal of Economic Behaviour and Organization, Vol. 8 (March 1987), pp. 13-38.

Edelman, M. J., The Symbolic Uses of Politics (Urbana, IL: University of Illinois Press, 1964).

Elster, J., Making Sense of Marx (Cambridge: Cambridge University Press, 1985).

Elster, J., Explaining Technical Change (Cambridge: Cambridge University Press, 1983).

Farrell, J., "Information and the Coase theorem," Journal of Economic Perspectives, Vol. 1 (Fall 1987), pp. 113-129.

Furet, F., Penser la Revolution Française (Paris: Gallimard, 1978).

Gould, S. J., The Panda's Thumb (New York: W. W. Norton, 1980).

Greenwald, B., and J. E. Stiglitz, "Externalities in economies with imperfect information and incompletc markets," Quarterly Journal of Economics, Vol. 101 (May 1986), pp. 229-264.

Hart, G., Power, Labour and Livelihood; Processes of Change in Rural Java (Berkeley, CA: University of California Press, 1986).

Hart, O., "Incomplete contracts and the theory of the firm," Journal of Law, Economics and Organization (forthcoming).

Hart, O., and B. Holmstrom, "The theory of contracts" in T. Bewley (Ed.), Advances in Economic Theory (Cambridge: Cambridge University Press, 1987).

Hayami, Y., and M. Kikuchi, Asian Village Economy at the Crossroads: An Economic Approach to Institu- tional Change (Baltimore: Johns Hopkins University Press, 1982).

Hayami, Y., and V. W. Ruttan, Agricultural Development: An International Perspective (Baltimore: Johns Hopkins University Press, 1985).

Kuran, T., "Preference falsification, policy continuity and collective conservatism," Economic Journal, Vol. 97 (Septemoer 1987), pp. 642-665.

Langlois, R. N., Economics as a Process: Essays in the New Institutional Economics (Cambridge: Cambridge University Press, 1986).

Leontief, W., "When should history be written backwards," Economic History Review, Vol. 16 (August 1963), pp. 1-8.

Marglin, S., "Knowledge and power," in F. H. Stephen (Ed.), Firms, Organization and Labour (London: Macmillan, 1984).

Menger, C., Problems of Economics and Sociology, 1883, translated by F. J. Nock (Urbana, IL: University of Illinois Press, 1963).

North, D. C., Structure and Change in Economic History (New York: W. W. Norton, 1981).

North, D. C., and R. Thomas, The Rise of the Western World (Cambridge: Cambridge University Press, 1973).

Nozick, R., Anarchy, State and Utopia (New York: Basic Books, 1974).

Roemer, J., A General Theory of Exploitation and Class (Cambridge, MA: Harvard University Press, 1982).

Schotter, A., The Economic Theory of Social Institutions (Cambridge: Cambridge University Press, 1981).

Stiglitz, J. E., "The new development economics," World Development, Vol. 14, No. 2 (February 1986), pp. 257-265.

Sugden, R., The Economics of Rights, Cooperation and Welfare (Oxford: Basil Blackwell, 1986).

Williamson, O. E., The Economic Institutions of Capitalism (New York: The Free Press, 1985). 